\title{
Restoration of On-farm Constructed Wetland Systems Used to Treat Agricultural Wastewater
}

\author{
Erin L. Smith ${ }^{1}$, Lisa Kellman ${ }^{2} \&$ Paul Brenton ${ }^{3}$ \\ ${ }^{1}$ Agriculture and Agri-Food Canada, Truro, NS, Canada \\ ${ }^{2}$ St. Francis Xavier University, Antigonish, NS, Canada \\ ${ }^{3}$ Nova Scotia Federation of Agriculture, Bible Hill, NS, Canada \\ Correspondence: Erin L. Smith, Agriculture and Agri-Food Canada, 361 Pictou Road, Truro, NS, Canada. E-mail: \\ erin.smith2@canada.ca
}

Received: December 12, 2018

Accepted: January 14, $2019 \quad$ Online Published: March 15, 2019

doi:10.5539/jas.v11n4p1

URL: https://doi.org/10.5539/jas.v11n4p1

\begin{abstract}
Two surface flow constructed wetland systems used to treat agricultural wastewater for over a decade were evaluated for their overall on-going treatment performance and future restoration need. Many on-farm constructed wetlands used for wastewater treatment in Atlantic Canada are now beginning to reach their saturation point and are no longer performing to their full operational potential. This study is an example of the process of evaluating when these systems are no longer viable; or are no longer functioning properly for wastewater treatment and outlines the steps necessary to restore their overall treatment capacities. On-farm constructed wetland restoration has been identified as a best management practice and can be accomplished successfully when important factors such as; landscape, hydrology, function, and the long-term farming goals are considered.
\end{abstract}

Keywords: constructed wetland, agriculture, wastewater treatment, wetland restoration, treatment efficiency, mass removal

\section{Introduction}

Constructed wetlands (CWs) have been found to provide a great service for reducing the environmental impacts from agricultural practices (Crumpton \& Baker, 1993; Schaafsma et al., 2000; Zelder, 2003; Smith et al., 2005a, 2015b). Interest in the use of CWs to treat farmyard runoff has increased in Eastern Canada over the past two decades due to the abundance of agricultural wastewater production and the need and interest in meeting necessary environmental standards. Since the conception of the Nova Scotia (NS) Environmental Farm Plan (EFP) Program in 1999 for example, on-farm environmental practices have greatly improved in NS. Due to the abundance of livestock farms, particularly dairy $(\sim 600)$ and beef $(\sim 1120)$ in the Atlantic Canadian region (Statistics Canada, 2014), there is still a need for wastewater treatment systems in the region.

Some producers are currently dealing with their waste through various means such as; manure and runoff containment (i.e. manure storage pad or concrete lagoons), land application, composting, dead-stock management, septic systems, vegetative filter strips, etc. There is still however a need for on-farm wastewater management in the Atlantic Canadian region. One of the most promising technologies for applications for small to mid-scale farms has been the use of $\mathrm{CW}$ systems due to their simple design and construction, operation and maintenance, and aesthetic appeal (Hammer, 1991, 1992; Cronk, 1996; Kadlec \& Knight, 1996; Smith et al., $2005 \mathrm{a}, 2005 \mathrm{~b}, 2006)$. There has been a renewed interest in CWs due to their cost effectiveness and eco-technology. Since the start of the EFP Program across Atlantic Canada, there has been a variety of farms who have implemented CWs to help deal with wastewater issues such as manure runoff, milkhouse washwater, etc. (NSEFP Program, 2015). These systems have been found to be very effective at treating a variety of different types of wastewaters for a number of years now. Many of these systems however are now 10-15 plus years old and require much needed attention in order to get them back to their original state to enhance overall treatment performance and effectiveness. A number of these systems have become saturated with nutrients, fecal coliforms and vegetation; hence these systems are no longer a sink for nutrients, but rather a source of nutrients. Some systems have even become clogged because of the decomposition of organic and inorganic solids, 
therefore leading to a build-up of sludge (DeVries, 1972). There is a lack of literature which currently exists outlining how producers, land or extension specialists should deal with the issue of wetland saturation for agricultural wastewater treatment purposes.

Much of the literature which exists on wetland restoration is with regards to natural wetland systems, or wetlands used for buffers and erosion control of storm-waters (i.e. coastal), peatlands, or wetlands used for ecological restoration (Mitsch \& Cronk, 1992; Galatowitsch \& van der Valk, 1996; Mitsch \& Wilson, 1996; Zelder \& Callaway, 1999; Keddy, 2000; Turner \& Streever, 2002; Zelder, 2003), not CWs designed for on-farm treatment purposes. Natural wetland systems are very different than $\mathrm{CWs}$, as they are not designed for wastewater treatment purposes. Therefore, there is a need to examine this process of $\mathrm{CW}$ restoration with on-farm, man-made systems. The objective of this paper aims to quantify water quality parameters in two agricultural CWs over a $14 \mathrm{yr}$ period. This paper aims to outline an example of some of the environmental considerations behind when it may be necessary to restore an existing agricultural $\mathrm{CW}$ and how one would go about carrying out this process. This paper outlines some of the issues and problems associated with aging agricultural $\mathrm{CW}$ systems, and presents ideas for restoring CWs back to their original state so that they can function as they once did.

\section{Research Methods}

\subsection{Site Description \& Design}

It is important to define wetland restoration for the purpose of this study. Restoration refers to returning the $\mathrm{CW}$ system back to its original state when wastewater treatment was achieved; or it may be also be defined as the action taken to halt the further decline of a $\mathrm{CW}$ system so that it is no longer a source for pollution.

Two agricultural CWs have been chosen for this investigation. These systems were surface flow (SF) wetlands $\left(100 \mathrm{~m}^{2}\right)$ that were designed and constructed in 2000 to continuously treat dairy wastewater, as well as domestic wastewater for a very short period of time. Hydraulic loading rates were variable over the monitoring period, however average five day biological oxygen demand $\left(\mathrm{BOD}_{5}\right)$ loading rates were $1500 \mathrm{mg} \mathrm{L}^{-1}$. Overall, the treatment performance of these systems was very good throughout the years, with $\mathrm{BOD}_{5}$ mass removals as high as $99 \%$ when treating dairy wastewater (Smith et al., 2006). The average retention time for both systems was 12 d. Both systems were constructed with two deep zones $(0.75-1 \mathrm{~m}$ in depth) and two shallow zones $(0.15-0.20 \mathrm{~m}$ in depth). A full description of these systems can be found in Smith et al. (2006). Yearly averaged minimum and maximum temperatures throughout the entire monitoring period were $-21^{\circ} \mathrm{C}$ to a maximum of $32^{\circ} \mathrm{C}$ (2000-2015).

After 14 years of operation, the CWs had become a real eye sore and treatment efficiency rates had decreased over time (Table 1). The CW systems were no longer able to hold water effectively. The polyethylene liners suffered impacts due to muskrat infestations (Figure 1), as well as the overall wear and tear from weather (i.e. sun degradation and ice movement). The wetlands had become overgrown with cattails, grasses, and weeds, as well as widespread algae in later years. The overgrowth in vegetation in the present study had choked the water pathway, and this prevented adequate water flow throughout the systems, resulting in a total system decline by 2013 (Figure 2), with less than a $50 \% \mathrm{BOD}_{5}$ removal rate. Due to these factors, in combination with poor water quality and odours associated with these systems, the systems could no longer be used for treating agricultural wastewater. The systems were now becoming a source of nutrients rather than a sink. This is a common situation facing many producers with CWs in the Atlantic Canadian region. The wetlands were therefore in need of restoration. Restoring these systems back to their original state was necessary so that they could be used again for on-farm treatment purposes. Producers in the region are facing a very similar situation and it is important for them, as well as their farm advisors to be able to recognize when this point has been reached and when restoration may be necessary. 
Table 1. Average mass removals for various water quality parameters in two constructed wetlands (W1 and W2) from the periods of 2000-2013 and 2014-2015

\begin{tabular}{llllll}
\hline \multirow{2}{*}{ Parameter $\left(\mathbf{m g ~ L}^{-\mathbf{1}}\right)$} & \multicolumn{2}{c}{ Mass Removals (\%) (2000-2013) } & & \multicolumn{2}{c}{ Mass Removals (\%) (2014-2015) } \\
\cline { 2 - 3 } & W1 & W2 & 62 & & W1 \\
\hline BOD $_{5}$ & 49 & 71 & & 98 & 99 \\
TP & 75 & 64 & 93 & 97 \\
SRP & 67 & 61 & 90 & 94 \\
TKN & 64 & 84 & 97 & 96 \\
TSS & 91 & 93 & 98 & 97 \\
FC & 97 & & 99 & 99 \\
\hline
\end{tabular}

Note. ${ }^{* \mathrm{FC}}$ were measured in $\mathrm{CFU} 100 \mathrm{~mL}^{-1}$.

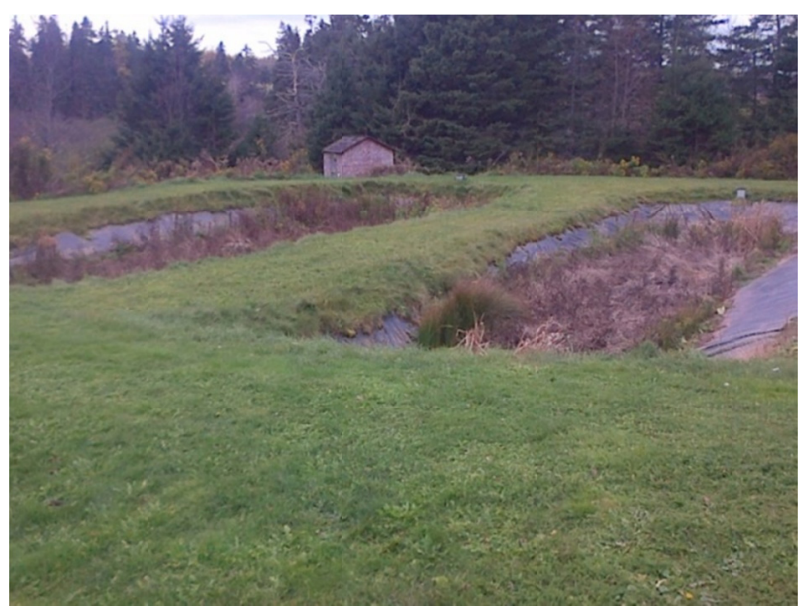

Figure 1. Two constructed wetlands located at Dalhousie University's Constructed Treatment Wetland Research Site in Bible Hill, NS before renovation in 2013 (after almost 14 years of operation)

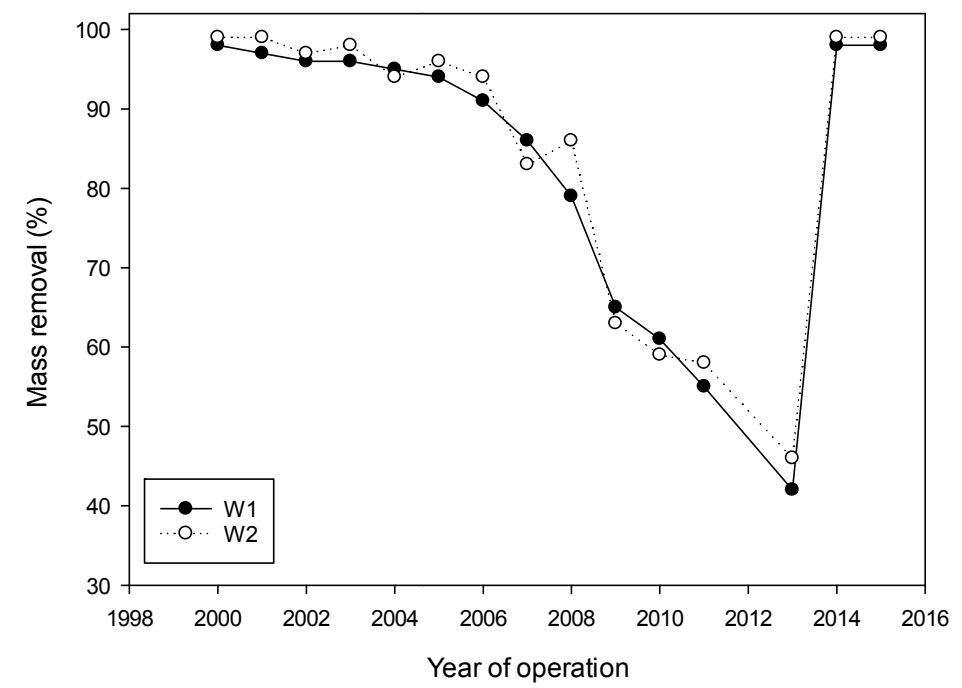

Figure 2. Average yearly biological oxygen demand $\left(\mathrm{BOD}_{5}\right)$ mass removals for $\mathrm{W} 1$ and $\mathrm{W} 2$ from the period of 2000-2015. Note that 2014 and 2015 was after the restoration

\subsection{Water Quality Monitoring}

One of the main issues of CWs on farms is that the water quality is not continuously monitored on a regular basis. Continuous or periodic monitoring is necessary to ensure that the systems are functioning properly. In the present study, samples were analyzed for; BOD $_{5}$ (APHA, 1989), total suspended solids (TSS), total kjeldahl nitrogen 
(TKN: Hach Method 8180), total phosphorus (TP: Hach method 8190), soluble reactive phosphorus (SRP: Hach method 8048), ammonia $\left(\mathrm{NH}_{3}-\mathrm{N}\right.$ : Hach Method 8038$)$, nitrate $\left(\mathrm{NO}_{3}{ }^{-} \mathrm{-N}\right.$ : using an ion specific electrode). Flow was measured using calibrated tipping buckets at both the inflow and outflow. Water samples were obtained regularly to aid in determining the overall wetland treatment performance and mass removal:

$$
\% \text { Mass Removal }=\frac{\left(\overline{\mathrm{C}}_{\text {in }} \times \Sigma \mathrm{Q}_{\text {in }}\right)-\left(\overline{\mathrm{C}}_{\text {out }} \times \Sigma \mathrm{Q}_{\text {out }}\right)}{\left(\overline{\mathrm{C}}_{\text {in }} \times \Sigma \mathrm{Q}_{\text {in }}\right)}
$$

where,

$\overline{\mathrm{C}}_{\mathrm{in}}=$ average monthly inflow concentration $\left(\mathrm{mg} \mathrm{L}^{-1}\right.$ or CFU $100 \mathrm{~mL}^{-1}$ in the case of $\left.\mathrm{FC}\right) ; \overline{\mathrm{C}}_{\text {out }}=$ average monthly outflow concentration (mg L${ }^{-1}$ or CFU $100 \mathrm{~mL}^{-1}$ in the case of FC); $\Sigma \mathrm{Q}_{\text {in }}=$ sum of the monthly flow volume into the wetland (L); $\Sigma \mathrm{Q}_{\text {out }}=$ sum of the monthly outflow volume out of the wetland (L).

Water samples were obtained from both the inlets and outlets from both wetlands throughout the period of 2000-2013 and post restoration in 2014-2015. Samples were obtained more frequently at the start of this study when the wetland renovation was completed and then on a monthly basis following regular operation.

In 2000, both wetlands were found to have a $\mathrm{BOD}_{5}$ mass removal of $99 \%$, compared to a $50 \%$ reduction in 2014 , after 14 years of operation. Figure 2 indicates the decrease in the $\mathrm{BOD}_{5}$ mass removals for both wetlands over time. Wetland mass removals were much higher in the earlier years of operation (2000-2008) with a more rapid decline following this period even though loading rates were kept relatively constant. The decline in average mass removal rates was however more pronounced following 10 years of operation (Figure 2). Phosphorus is generally considered to be the limiting nutrient within these systems when determining if their saturation point has been reached (Richardson \& Craft, 1993; Sakadevan \& Bavor, 1998; Drizo et al., 2002; Dong et al., 2005). In the present study, TKN and SRP appear to have been the limiting nutrients in the examined systems, as their mass removal rates had declined significantly pre-restoration (Table 1).

A visual detailed inspection was performed at the study site each fall during the monitoring period; results are presented in Table 2. Results indicate some of the visible challenges. Results indicate that visual challenges started to present themselves in 2011 (i.e. stagnant water, odours, dark water color, holes in the liner, and increased vegetation growth). These are some of the indicators a producer should be aware of when using an on-farm wetland system.

Table 2. Visual inspection of the constructed wetlands (W1 and W2) in September of each year monitored (2000-2015)

\begin{tabular}{|c|c|c|}
\hline \multirow{2}{*}{ Year } & \multicolumn{2}{|c|}{ Visual Observations } \\
\hline & W1 & W2 \\
\hline 2000 & water clear, many species present, cattails planted (one per $\mathrm{m}^{2}$ ) & Water clear, many species present, cattails planted (one per $\mathrm{m}^{2}$ ) \\
\hline 2001 & water clear, many species present & water clear, many species present \\
\hline 2002 & water clear, many species present & water clear, many species present \\
\hline 2003 & lemna plants present, very dry period & lemna plants present, very dry period \\
\hline 2004 & water clear, many species present & water clear, many species present \\
\hline 2005 & water clear, many species present & water clear, many species present \\
\hline 2006 & water clear, many species present & water clear, many species present \\
\hline 2007 & water clear, many species present & water clear, many species present \\
\hline 2008 & water clear, many species present & water clear, many species present \\
\hline 2009 & water clear, many species present & water clear, many species present \\
\hline 2010 & water clear, many species present & water clear, many species present \\
\hline 2011 & $\begin{array}{l}\text { stagnant water, odours present, water black, } \\
\text { vegetation overgrown, holes in liner }\end{array}$ & $\begin{array}{l}\text { stagnant water, odours present, water black, } \\
\text { vegetation overgrown, holes in liner }\end{array}$ \\
\hline 2012 & wetland is now a source of pollutants & wetland is now a source of pollutants \\
\hline 2013 & no water present, holes in liner, vegetation overgrowth, odours & no water present, holes in liner, vegetation overgrowth, odours \\
\hline 2014 & water clear, aerated, cattails doing very well $\left(10\right.$ per $\left.\mathrm{m}^{2}\right)$ & water clear, cattails healthy $\left(11\right.$ per $\left.\mathrm{m}^{2}\right)$ \\
\hline 2015 & water clear, aerated, cattails healthy $\left(15\right.$ per $\left.\mathrm{m}^{2}\right)$ & water clear, cattails healthy $\left(17\right.$ per $\left.\mathrm{m}^{2}\right)$ \\
\hline
\end{tabular}

A weather station was also established at the site to determine meteorological impacts on wetland performance. Parameters measured included; air temperature, relative humidity, water temperature $(0.10$ and $1 \mathrm{~m})$, precipitation, solar radiation, wind speed and direction. The only indication that weather had an impact on 
overall performance was when evapotranspiration rates were high and precipitation was low. The lack of water resulted in very little outflow, hence resulting in vegetation growing at a faster rate, primarily weeds, grasses and cattails, which contributed to short-circuiting throughout the wetlands. Contrary, when there were heavy rainfall periods, the wetlands were diluted, but mass removal calculations reported in this study accounted for this dilution effect. When wind speeds increased the on-site $4.9 \mathrm{~m}$ windmill increased overall aeration enhancing overall treatment by up to $20 \%$ (Figure 3 ).

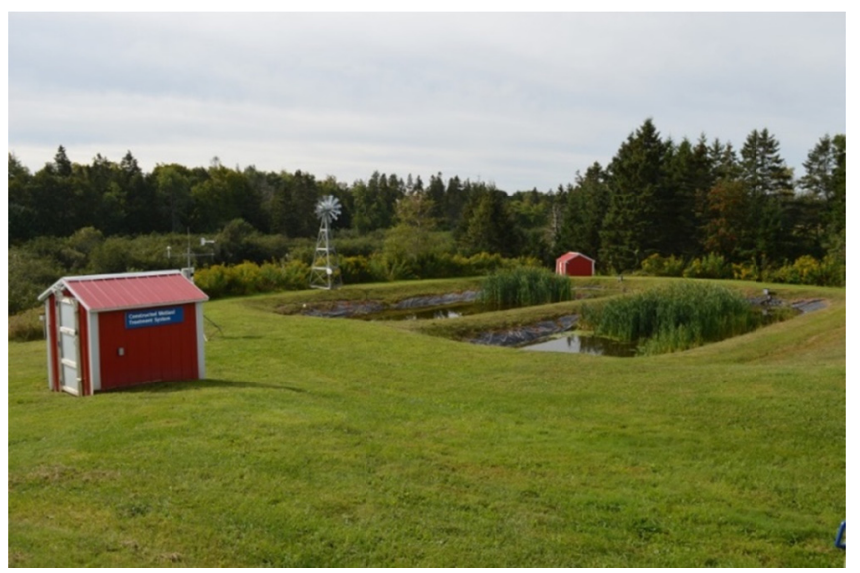

Figure 3. Newly renovated wetland systems at Dalhousie University Constructed Wetland Treatment Research Site, Bible Hill, NS after renovation in 2014. A windmill was included for aeration purposes

\section{Identification of Restoration Need}

Water quality in an agricultural $\mathrm{CW}$ system is commonly defined as the reduction in concentration of $\mathrm{BOD}_{5}$, $\mathrm{TP}$ and TKN. Constructed wetlands are known for their ability to reduce the sediment loading into nearby water ways. In the present study, manure storage tanks provided some primary treatment by allowing a space for the settling of solids. By having some form of primary treatment for sediment removal others have suggested it will help to promote increased longevity (Cronk, 1996; Almendinger, 1999; Knight et al., 2000; Vymazal, 2005). The present study also supports this finding. Wetland vegetation within the shallow zones also aided in trapping sediments as well (Braskerud, 2001). This finding was also apparent throughout the shallow vegetated zones of the wetlands in the present study; sediment build-up was approximately $10 \mathrm{~cm}$ throughout these zones.

When carrying out the restoration of an on-farm $\mathrm{CW}$ care must be taken to discuss issues with the producer and address any treatment, or on-site concerns they may be having. Care must also be taken to address both the causes and symptoms of the wetland degradation and treatment capability (i.e. wastewater too concentrated, animal infestation, overgrown vegetation, not enough treatment area, etc.). A discussion should also be held with a qualified agricultural engineer as well, to ensure the proper design, and also to ensure that environmental guidelines are being met. Construction and restoration is a step by step process where many aspects should be considered at the farm-level, for instance; (i) has the farm priorities changed, (ii) has the concentration or volume of wastewater to be treated changed since the original wetland was constructed, and (iii) what are the long-term plans of the producer and the surrounding property. Consideration of all these factors is important before restoration begins to ensure that the right goals are being addressed. If the wastewater parameters and volume are expected to stay the same, then the wetland design may remain the same if adequate treatment was previously achieved and restoration can begin. If however, there are changes to the on-farm operation, for instance the volume of wastewater, type of wastewater, proximity of other buildings, manure storage, animal grazing pressure, etc. these must be considered first before restoration begins. More or less surface area may then be required for the restoration or new construction.

Wetlands also play a significant role in enhancing on-farm biodiversity (Hansson et al., 2005; Zhang et al., 2008; Thiere et al., 2009; Hsu et al., 2011) and it is important that we preserve these very important systems. One of the main reasons for ensuring that on-farm wetlands get restored is to reduce the degradation of species biodiversity (Markwell \& Fellows, 2008; Zhang et al., 2008). Enhancing on-farm biodiversity is key to ensuring environmental sustainability and overall success. In the Atlantic Canadian region, producers are encouraged to also look at on-farm biodiversity. In Nova Scotia (NS) for example, Environmental Farm Planners are 
recommending that farms also conduct an Agricultural Biodiversity Conservation (ABC) plan as part of their overall Environmental Farm Plan.

On a farm there is often a wide variety of different types of habitats in a relatively small area (i.e. wetlands, woodlands, fields, etc.). Because of this, they tend to foster high amounts of biodiversity. An ABC plan is administered by a program provided by the Department of Lands \& Forestry where the biodiversity on the farm is examined and suggestions are made to the farm owner on how to protect and encourage this biodiversity going forward. The ABC program has been running for 10 years in NS and has examined over 15,000 ha of land on more than 180 farms. The ABC plans are provided free of charge to the producer and are available for any type of farm in NS of any size, and there is no obligation to the farm owner to act on any of the recommendations provided in the plan. The onsite examination takes 1-3 d depending on the farm size, and then a report is produced based on the farm assessment. This report outlines the different habitats on the farm, the common species found within those habitats, and what practices can be undertaken to help protect those environments. Often the practices that farm owners are following are already encouraging the local biodiversity, in these cases the $\mathrm{ABC}$ plan works to educate owners on the beneficial impacts of what they are doing and the impacts it has on the local biodiversity. This encourages them to make similar choices as they continue to develop their operation.

\subsection{Visual Inspection}

After 14 years of operation the water within the present wetland systems were either non-existent in some zones or was black/dark and very stagnant in other zones. The liners were severely damaged by an infestation of muskrats, as well as some plant roots and the normal weather degradation. Total $\mathrm{P}$ was high in both systems (Table 1), indicating that both of these wetlands had become saturated, meaning they started to become a source of pollution rather than a sink for excess nutrients. This is similar to the observations made by Koskiatho et al. (2003) and Smith et al. (2006). Both studies also saw overly stressed agricultural CWs becoming a source instead of a sink of total P.

The lack of wildlife present was also an indication of wastewater overloading and reduced treatment capacity. Wildlife could no longer live in the wetland or sustain themselves based on the current toxic water conditions. Water that was in existence was starting to become stagnant and odours were present. If there is a presence of algae for prolonged periods of time it is important to be aware that this may indicate that the system has been overloaded with nutrients and inflow volume or wastewater concentration should likely be reduced. Reducing the inflow will help if the wetland has not already reached its saturation point. At times, inflow concentration may not be the problem. High nutrient levels may be coming from an influx of ducks for example. It is important to identify the source of these nutrients. In the present study, vegetation was very overgrown and cattails within each shallow zone were at a density of approximately 22 per square meter, compared to the recommended one cattail every square meter at the time of planting (U.S. EPA, 1988). Increased vegetation also contributed to a blockage in free water flow throughout the wetland systems due to the increase in plant density. The high density caused short-circuiting of water within the system which was problematic for adequate treatment. The short-circuiting did not allow for adequate retention time.

There has been plenty of research done on the different set backs that many CWs face. Braskerud (2002) found, in a study examining the $\mathrm{N}$ retention of four surface flow CWs in Norway for 3 to 7 yrs, that the $\mathrm{N}$ retention decreased as the wetlands aged. Similarly, Liikanen et al. (2006) looked at the greenhouse gas emissions of a $\mathrm{CW}$ used to purify peat mining runoff in 1992 and in 2001-2002. They found that the $\mathrm{CH}_{4}$ emissions had doubled and the $\mathrm{CO}_{2}$ emissions had tripled in the $10 \mathrm{yr}$ gap. This was believed to be caused by increased plant biomass and a higher average temperature.

Another common issue to CWs is the overloading of the systems. In a CW examined by Newman et al. (1999) designed to treat milkhouse wastewater, it was found that the wetland was being overloaded, especially by $\mathrm{BOD}_{5}$. This lead to multiple issues, including decreased nutrient reduction and the inability to estimate the wetland's treatment efficiency using its retention time. Relatedly, a study by Harrington and Scholz (2010) examining the use of CW to treat waste from pig farms found that the replicate with the highest flow rates $\left(>100 \mathrm{~m}^{3} / \mathrm{ha} / \mathrm{d}\right)$ had difficulty with ammonia-N removal leading to both air and water pollution. This was likely due to the system being overloaded, highlighting the importance of using a $\mathrm{CW}$ that is sized appropriately to handle the expected inflow of a system.

Relatedly, a study by Barton and Karathanasis (1999) examined a CW used for acid mine drainage water (not agriculture) failed due to inadequately using the treatment surface area, overloading, and inadequate alkalinity production. Clogging has been recognized as a major factor in decreasing CW longevity (Winter \& Goetz, 2003; Lianfang et al., 2009). This is something however that is preventable. It is important for agricultural producers to 
keep in mind that $\mathrm{CW}$ should not be designed as a primary treatment system, meaning they cannot handle significant amount of solids. It is therefore important for producers to have a settling tank or settling pond to capture most of the solids before it enters a wetland system. Pre-treatment is very important to the longevity of the system (Cronk, 1996; Knight et al., 2000; Vymazal, 2009).

A study done by Koskiaho et al. (2003) examined CW and their ability to retain nutrients under boreal conditions. Of the three wetlands examined in that study, the wetland with the shortest retention time often became a net source of dissolved reactive phosphorous and $\mathrm{NO}_{3}{ }^{-} \mathrm{N}$. Retention time has a large impact on a CW's ability to filter nutrients, as many of the filtering processes take time to be enacted (Stottmeister et al., 2003). Therefore, it is important when creating CWs to make sure that they are designed to a large enough size and in such a way that inflow spreads evenly across the entire CW. Pries et al. (1996) examined data from 68 different CWs in the northern United States and southern Canada. Similarly, to Barton and Karathanasis (1999) and Pries et al. (1996) they found that CWs without adequate pre-treatment facilities often had a buildup of solids inside of them which impaired the efficiency of nutrient removal by covering over the microorganisms that were providing treatment, and by reducing the hydraulic residence time in the $\mathrm{CW}$. Without proper pre-treatment the $\mathrm{CW}$ was unable to process nutrients as efficiently and had less time to do so.

System type is also something that needs consideration at the farm level (i.e. surface flow or subsurface flow wetlands). There are pros and cons to each type of wetland system. Surface flow wetlands are most often cheaper to install, but when compared to subsurface flow wetlands they tend to have a lower efficiency of contaminate removal (Lee et al., 2009). Subsurface wetlands can be divided into two sub-types based on the direction of the flow water, horizontal flow and vertical flow. Horizontal flow CWs tend to lack the ability to provide nitrification due to being a mostly anaerobic environment. Vertical flow CWs on the other hand, lack the ability to provide effective denitrification. It is possible to combine the features of vertical and horizontal flow CWs to create a hybrid system that has the benefits of both (Lee et al., 2009).

Seasonal variability is often another concern when incorporating a CW into a farm. If a farm is in a cold climate then using a CW during all seasons could lead to unique obstacles during the winter months. These obstacles can include hydrology and hydraulic issues caused by freezing of the surface water, as well as chemical and microbial processes that may be adversely affected (Smith et al., 2006). There are multiple options for how to handle these issues. If a producer can afford the cost of storage they can store wastewater created during the winter and release it into the CW after the winter months (Pries et al., 1996). Alternatively, different forms of insulation have been shown to be effective, including mulch, compost or straw (Steiner \& Watson 1993; Wallace et al., 2000). Lastly, Smith et al. (2006) insulated the CW in their study by raising the water depths in the winter months, then allowing the surface layer to freeze over naturally, and then returning the water depth back to its original level, creating a pocket of air. This management practice worked well for continuing the treatment throughout the winter months but does require some management.

\subsection{Site Restoration Work}

Once restoration began it was clear that there was a lot of sediment in the bottom of the wetland. Even though the wastewater storage tanks did provide some pre-treatment for sediment removal, solids did also accumulate across all zones in each system.

Excavation began by the removal of all vegetation and all the saturated soil, vegetation was composted and soil was land applied. The polyethylene liner was also removed due to the fact that the vegetation began to create holes in the liner and the sunlight overtime had degraded it. The soil beneath the liner was then inspected for any structures such as pipes, rocks, etc. This was to ensure there would be no punctures in the new liner. This work consisted of layering and compacting the soil in both deep and shallow zones. The new liner was then manually installed and a nice tight seal was achieved by the construction of surrounding berms. Berms were constructed using a 2:1 slope to ensure adequate bank stabilization and for the security of the liner. Installation of a liner is necessary if soils at the site are particularly sandy and do not have an adequate water holding capacity. The use of a liner can help to prevent groundwater contamination. Typical pond-liners are expected to have a life-span of $8-12$ yrs if maintained properly.

Once the liners were installed approximately $0.20 \mathrm{~m}$ of soil was placed in the bottom of each shallow zone to act as a bed for vegetation that was later planted. Cattails were planted at a density of 1 every $1 \mathrm{~m}^{2}$ in all shallow zones. Once cattails were planted securely, water was then placed into each wetland slowly to ensure that the soil remained in position (Figure 4).

Both wetlands had an inflow (center of $1^{\text {st }}$ deep zone) and outflow pipe (center of the last shallow zone). Each pipe was connected to an Agri-Drain to allow for outflow to be stopped if needed. Agri-Drains are not necessary 
though for most on-farm systems. The surrounding landscape was then levelled and highway mix seed was planted to encourage grass growth for bank stabilization.

This study site has not only acted as a research site, but it has been a great demonstration site for producers in the region. Many producers have visited the site to see first-hand what a $\mathrm{CW}$ is, how they are constructed, what landscape and wastewater factors must be considered when designing a system, and how one could go about restoring an already existing system. Interest in this cost-effective strategy has been increasing which has been nice to see.

\subsection{Performance Efficiency}

Figure 2 shows a steep decline in average yearly biological oxygen demand $\left(\mathrm{BOD}_{5}\right)$ mass removals for $\mathrm{W} 1$ and W2 starting in 2004 and continuing until the restoration in 2014. This decline was likely caused by several factors; including the accumulation of solids. Pries et al. (1996) had found that when solids accumulate they can cause lower retention time in the wetland and interfere with many of the microorganisms that are responsible for processing nutrients. Also, the large amount of overgrowth present in the system likely lowered retention time of the wetland and lead to a short circuiting of the CW's usual flow pattern. These findings support what was found by Braskerud (2002), where the amount of $\mathrm{N}$ retention decreases as the $\mathrm{CW}$ ages.

Artificial aeration in CWs have been found to increase their nutrient removal capabilities, especially in cold climates. Although oxygen solubility is increased during colder weather, the dormancy of local plant life often creates a low oxygen environment causing low levels of organic matter decomposition (Ouellet-Plamondon et al., 2006). To combat this, many CWs use artificial aeration methods to help maintain an aerobic environment. Figure 4 demonstrates the visual differences between wetlands with and without aeration under peak flow periods. In the $\mathrm{CW}$ lacking aeration, there is layer of algae present suggesting an overloading of nutrients.

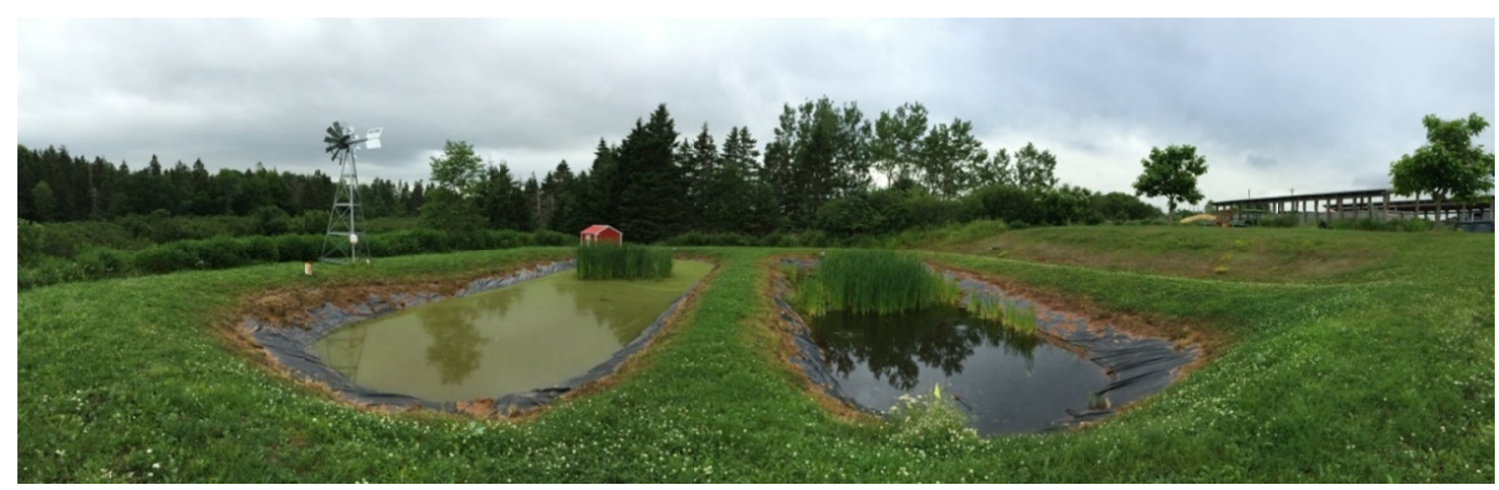

Figure 4. Photo of the two constructed wetland systems, without aeration (left) and with aeration (right)

It has been found that artificial aeration can also increase a CW's ability to process nitrogen. Both Ouellet-Plamondon et al. (2006) and Maltais-Landry et al. (2009c) studied the N processing through seasonal variations and the presence or absence of artificial aeration. Maltais-Landry et al. (2009c) found that the removal of TN was highest during the summer in the aerated plots and Ouellet-Plamondon (2006) found that artificial aeration increased the removal of TKN in both the summer and winter. Similarly, in a separate study done by Maltais-Landry et al. (2009a), aerated CW were found to more efficiently process and transform N, releasing a higher rate of oxidized $\mathrm{N}$ as (over ammonium) than the non-aerated units. In that study, it was also determined that the aerated units had reduced levels of greenhouse gas flux (Maltais-Landry et al., 2009a).

Much research has been done on how artificial aeration affects $\mathrm{CW}$ greenhouse gas emissions. In multiple studies done by Maltais-Landry et al. (2009c), it has been found that the introduction of artificial aeration had decreased the flux of greenhouse gases (2009a and b). However, in a study done by Mander et al. (2011), it was found that the methods used to increase aeration also increased the $\mathrm{N}_{2} \mathrm{O}$ flux. It is possible that this differences in findings were in part due to differences in the method and frequency of aeration (Mander et al., 2011). Mander et al. (2014) suggested that when weighing the pros and cons of artificial aeration on the atmosphere, greenhouse gases released to generate any electricity required for the process should also be taken into consideration. However, aeration systems with low environmental impact are effective as demonstrated with the aeration method used in this project (Figure 3). 
In both W1 and W2, species richness increased significantly (vegetation and wildlife) over time based on a visual inspection of the wetlands. Wetlands with higher biodiversity tend to have higher ecosystem sustainability and nutrient removal efficiency (Bachand \& Horne, 2000; Liu et al., 2009; Zhang et al., 2011; Chang et al., 2014). However, Chang et al. (2014) also noticed that although species richness lead to an increase in the efficiency of $\mathrm{N}$ removal in $\mathrm{CW}$, they also saw a rise in greenhouse gas emissions. Therefore it is possible that higher biodiversity may come at an atmospheric cost though the research suggests that this negative is out weighed by the benefits that a high biodiversity can provide.

\section{Conclusion}

There has been renewed interest in the use of on-farm CWs due to their cost-effectiveness and how eco-friendly the technology is. Constructed wetlands have been found to be very effective at treating agricultural wastewater for many years. Wetland restoration has been found to be a best management practice (BMP) that can improve water quality bordering agricultural areas. Wetland restoration can be a cost effective treatment option that should be investigated before investigation other man-made options (i.e. woodchip bioreactor, digesters, etc.). The present study determined that these wetlands functioned very well when continually loaded for more than 10 yrs. Maintenance and continued water quality monitoring however is key for on-farm CWs that are to be used for treatment purposes to ensure that these systems are functioning properly. Constructed wetlands do require regular visual and water quality checks to ensure proper functioning is occurring and that there are no environmental hazards taking place. Pre-treatment for sediment removal will also help to increase the life-span of the wetland and careful monitoring and managing are key to the long-term success of these systems. Producers do however need to be aware that these systems will not last forever, and that the determined lifespan will depend on a variety of factors such as; loading rate, wastewater type, climate, vegetation density, soil type/condition of the liner, and species present.

It is very important for producers to sit down with a wetland expert and an agricultural engineer to discuss what their long-term farming goals are and what they will require on a daily basis for their current and future farming practices. Important points of consideration and discussion should include; (i) what type of wastewater will be treated, (ii) what is the average/expected maximum and minimum flows, (iii) what are the water quality parameters of concern, and (iv) what are the long-term goals of the farm and how might the flows change in the future. Discussions involving these questions; coupled with proper design and management will help to ensure the long-term viability of these systems. The overall restoration of an on-farm wetland should be a multi-disciplinary effort; the role that wetlands play as a climate adaptation option for flood abatement, their role in on-farm nutrient interception, as well as their role in enhancing on-farm biodiversity should all be considered to ensure that the full potential of the wetlands are being met.

\section{Acknowledgements}

This research would also not have been possible without the funding provided by Agriculture and Agri-Food Canada and Dalhousie University. Special thanks to Becky McDonald and Doug Burris for all their valuable technical expertise, and summer student Emily Davis for help with sampling and field activities.

\section{References}

Almendinger, J. E. (1999). A method to prioritize and monitor wetland restoration for water-quality improvement. Wetl. Ecol. Manag, 6, 241-251. https://doi.org/10.1023/A:1008439031165

APHA (American Public Health Association). (1989). Standard methods for the examination of water and wastewater (17th ed., pp. 3-1-4-110). APHA. Washington, DC.

Bachand, P. A. M., \& Horne, A. J. (2000). Denitrification in constructed free-water surface wetlands: II. Effects of vegetation and temperature. Ecol. Eng., 14, 17-32. https://doi.org/10.1016/S0925-8574(99)00017-8

Barton, C. D., \& Karathanasis, A. D. (1999). Renovation of a failed constructed wetland treating acid mine drainage. Environ. Geol., 39(1), 39-50. https://doi.org/10.1007/s002540050435

Braskerud, B. C. (2001). The influence of vegetation on sedimentation and resuspension of soil particles in small constructed wetlands. J. Environ. Qual., 30(4), 1447-57. https://doi.org/10.2134/jeq2001.3041447x

Braskerud, B. C. (2002). Factors affecting nitrogen retention in small constructed wetlands treating agricultural non-point source pollution. Ecol. Eng., 18(3), 351-370. https://doi.org/10.1016/S0925-8574(01)00099-4

Chang, J., Fan, X., Sun, H., Zhang, C., Song, C., Chang, S. X., ... Ge, Y. (2014). Plant species richness enhances nitrous oxide emissions in microcosms of constructed wetlands. Ecol. Eng., 64, 108-115. https://doi.org/ 10.1016/j.ecoleng.2013.12.046 
Cronk, J. K. (1996). Constructed wetlands to treat wastewater from dairy and swine operations. Agric. Ecosyst. Environ., 58, 97-108. https://doi.org/10.1016/0167-8809(96)01024-9

Crumpton, W. G., \& Baker, J. L. (1993). Integrating wetlands into agricultural drainage systems: Predictions of nitrate and loss in wetlands receiving agricultural subsurface drainage. Am. Soc. Agric. Eng., 118-126.

DeVries, J. (1972). Soil filtration of wastewater effluent and the mechanism of pore clogging. J. Water Pollut. Control Fed., 44, 565-573.

Dong, C. S., Ju, S. C., Hong, J. L., \& Jong, S. H. (2005). Phosphorus retention capacity of filter media for estimating the longevity of constructed wetland. Water Res., 39(11), 2445-2457. https://doi.org/10.1016/ j.watres.2005.04.032

Drizo, A., Comeau, Y., Forget, C., \& Chapuis, R. P. (2002). Phosphorus saturation potential: A parameter for estimating the longevity of constructed wetland systems. Environ. Sci. Technol., 36(21), 4642-4648. https://doi.org/10.1021/es011502v

Galatowitsch, S. M., \& van der Valk, A. G. (1996). The vegetation of restored and natural prairie wetlands. Ecol. Appl., 6, 102-112. https://doi.org/10.2307/2269557

Hach. (1992). Hach water analysis handbook (2nd ed.). Hach Company, Loveland, Colorado.

Hammer, D. A. (1991). Constructed wetlands for wastewater treatment-municipal, industrial and agricultural. Lewis Publishers, Chelsea, Michigan.

Hammer, D. A. (1992). Creating freshwater wetlands. Lewis Publishers. Boca Raton, FL, USA.

Hannsson, L. A., Brönmark, C., Anders Nilsson, P., \& Åbjörnsson, K. (2005). Conflicting demands on wetland ecosystem services: Nutrient retention biodiversity or both? Freshw. Biol., 50, 705-714. https://doi.org/ 10.1111/j.1365-2427.2005.01352.x

Harrington, C., \& Scholz, M. (2010). Assessment of pre-digested piggery wastewater treatment operations with surface flow integrated constructed wetland systems. Biores. Technol, 101(20), 7713-7723. https://doi.org/ 10.1016/j.biortech.2010.03.147

Hsu, C. B., Hsieh, H. L., Yang, L., Wu, S. H., Chang, J. S., Hsiao, S. C., Su, H. C., ... Lin, H. J. (2011). Biodiversity of constructed wetlands for wastewater treatment. Ecol. Eng., 37(10), 1533-1545. https://doi.org/10.1016/j.ecoleng.2011.06.002

Kadlec, R. H., \& Knight, R. L. (1996). Treatment wetlands. CRC Press, Inc. Boca Raton, FL, USA.

Keddy, P. A. (2000). Wetland ecology: Principles and conservation. Cambridge, UK: Cambridge University Press. https://doi.org/10.1672/0277-5212(2000)020\%3C0565:R\%3E2.0.CO;2

Knight, R. L., Payne, V. W. E., Borer, R. E., Clarke, R. A., \& Pries, J. H. (2000). Constructed wetlands for livestock wastewater management. Ecol. Eng., 15(1-2), 41-55. https://doi.org/10.1016/S0925-8574(99) 00034-8

Koskiaho, J., Ekholm, P., Räty, M., Riihimäki, J., \& Puustinen, M. (2003). Retaining agricultural nutrients in constructed wetlands-experiences under boreal conditions. Ecol. Eng., 20, 89-103. https://doi.org/10.1016/ S0925-8574(03)00006-5

Lee, C., Fletcher, T. D., \& Sun, G. (2009). Nitrogen removal in constructed wetland systems. Review. Eng. Life Sci., 9(1), 11-22. https://doi.org/10.1002/elsc.200800049

Lianfang, Z., Wei, Z., \& Wei, T. (2009). Clogging processes caused by biofilm growth and organic particle accumulation in lab-scale vertical flow constructed wetlands. J. Environ. Sci., 21, 750-757. https://doi.org/ 10.1016/S1001-0742(08)62336-0

Liikanen, A., Huttunen, J. T., Karjalainen, S. M., Heikkinen, K., Vaisanen, T. S., Nykanen, H., \& Martikainen, P. J. (2006). Temporal and seasonal changes in greenhouse gas emissions from a constructed wetland purifying peat mining runoff waters. Ecol. Eng., 26(3), 241-251. https://doi.org/10.1016/j.ecoleng. 2005.10.005

Liu, D., Ge, Y., Chang, J., Peng, C., Gu, B., Chan, G. Y. S., \& Wu, X. (2009). Constructed wetlands in China: recent developments and future challenges. Front. Ecol., 7(5), 261-268. https://doi.org/10.1890/070110

Maltais-Landry, G., Maranger, R., \& Brisson, J. (2009a). Effect of artificial aeration and macrophyte species on nitrogen cycling and gas flux in constructed wetlands. Ecol. Eng., 35(2), 221-229. https://doi.org/10.1016/ j.ecoleng.2008.03.003 
Maltais-Landry, G., Maranger, R., Brisson, J., \& Chazarenc, F. (2009b). Greenhouse gas production and efficiency of planted and artificially aerated constructed wetlands. Environ. Pollut., 157(3), 748-754. https://doi.org/10.1016/j.envpol.2008.11.019

Maltais-Landry, G., Maranger, R., Brisson, J., \& Chazarenc, F. (2009c). Nitrogen transformations and retention in planted and artificially aerated constructed wetlands. Water Res., 43(2), 535-545. https://doi.org/10.1016/ j.watres.2008.10.040

Mander, U., Dotro, G., Ebie, Y., Towprayoon, S., Chiemchaisri, C., Nogueira, S. F., ... Mitsch, W. J. (2014). Greenhouse gas emission in constructed wetlands for wastewater treatment: A review. Ecol. Eng., 1-17. https://doi.org/10.1016/j.ecoleng.2013.12.006

Mander, U., Maddison, M., Soosaar, K., \& Karabelnik, K. (2011). The impact of pulsing hydrology and fluctuating water table on greenhouse gas emissions from constructed wetlands. Wetlands, 31(6), 1023-1032. https://doi.org/10.1007/s13157-011-0218-z

Markwell, K. A., \& Fellows, C. S. (2008). Habitat and biodiversity of on-farm water storages: A case in Southeast Queensland, Australia. Environ. Manage, 41, 234-249. https://doi.org/10.1007/s00267-0079037-7

Mitsch, M. J., \& Cronk, J. K. (1992). Creation and restoration of wetlands: Some design consideration for ecological engineering. Soil Restoration. Adv. Soil Sci., 17, 217-259. https://doi/org/10.1007/978-1-4612-28 20-2_8

Mitsch, W. J., \& Wilson, R. F. (1996). Improving the success of wetland creation and restoration with know-how, time and self-design. Ecol. Appl., 6(1), 77-83. https://doi.org/10.2307/2269554

Newman, J. M., Clausen, C. C., \& Neafsey, J. A. (1999). Seasonal performance of a wetland constructed to process dairy milkhouse wastewater in Connecticut. Ecol. Eng., 14(1-2), 181-198. https://doi.org/10.1016/ S0925-8574(99)00028-2

NSEFP Program (Nova Scotia Environmental Farm Plan Program). (2015). Retrieved from http://www.nsfa-fane. $\mathrm{ca} / \mathrm{efp} /$ NovaScotia Federation of Agriculture

Ouellet-Plamondon, C., Chazarenc, F., Comeau, Y., \& Jacques, B. (2006). Artificial aeration to increase pollutant removal efficiency of constructed wetlands in cold climate. Ecol. Eng, 27(3), 258-264. https://doi.org/ 10.1016/j.ecoleng.2006.03.006

Pries, J. H., Borer, R. E., Clarke, R. A., Jr., \& Knight, R. L. (1996). Performance and design considerations of treatment wetland systems for livestock wastewater management in cold climate regions in the northern United States and southern Canada. Proceedings: Second National Workshop on Constructed Wetlands for Animal Waste Management.

Richardson, C. J., \& Craft, C. B. (1993). Effective phosphorus retention in wetlands: Fact or fiction. In G. A. Moshiri (Ed.), Constructed Wetlands for Water Quality Improvement (pp. 271-282). Lewis Publishers, Boca Raton.

Sakadevan, K., \& Bavor, H. J. (1998). Phosphate adsorption characteristics of soils, slags and zeolite to be used as substrates in constructed wetland systems. Water Res., 32(2), 393-399. https://doi.org/10.1016/S004 3-1354(97)00271-6

Schaafsma, J. A., Baldwin, A. H., \& Streb, C. A. (2000). An evaluation of a constructed wetland to treat wastewater from a dairy farm in Maryland, USA. Ecol. Eng., 14, 199-206. https://doi.org/10.1016/S09258574(99)00029-4

Smith, E., Gordon, R., Madani, A., \& Stratton, G. (2005a). Pathogen removal by agricultural constructed wetlands in cold climates. J. Environ. Inf., 6(1), 46-50. https://doi.org/10.3808/jei.200500054

Smith, E., Gordon, R., Madani, A., \& Stratton, G. (2005b). Cold climate hydrological flow characteristics of constructed wetlands. Can. Biosyst. Eng., 47, 1.1-1.7.

Smith, E., Gordon, R., Madani, A., \& Stratton, G. (2006). Year-round treatment of dairy wastewater by constructed wetlands in Atlantic Canada. Wetlands J., 26(2), 349-357. https://doi.org/10.1672/0277-5212 (2006)26[349:YTODWB]2.0.CO;2

Statistics Canada. (2014). Table 002-0044 Detailed average operating revenues and expenses of farms, by farm type, incorporated and unincorporated sectors, Canada and provinces, annual (dollars unless otherwise noted). CANSIM (database). Retrieved March 30, 2016, from http://www5.statcan.gc.ca/cansim/a47 
Steiner, G. R., \& Watson, J. T. (1993). General design construction, and operation guidelines: Constructed wetlands wastewater treatment systems for small users including individual residences. Tennesse Valley Authority, Chattanooga, TN, United States. https://doi.org/10.2172/10105386

Stottmeister, U., Wiebner, A., Kuschk, P., Kappelmeyer, U., Kästner, M., Bederski, O., ... Moormann, H. (2003). Effects of plants and microorganisms in constructed wetlands for wastewater treatment. Biotechnol. Adv., 22(1-2), 93-117. https://doi.org/10.1016/j.biotechadv.2003.08.010

Thiere, G., Milenkovski, S., Lindgren, P. E., Sahlén, G., Berglund, O., \& Weisner, S. E. B. (2009). Wetland creation in agricultural landscapes: Biodiversity benefits on local and regional scales. Biol. Conserv., 142(5), 964-973. https://doi.org/10.1016/j.biocon.2009.01.006

Turner, R. E., \& Streever, B. (2002). Coastal wetland restoration. Wetlands, 22(4), 801-802. https://doi.org/ 10.1672/0277-5212(2002)022[0801:R]2.0.CO;2

U.S. EPA. (1988). Design manual-constructed wetlands and aquatic plant systems for municipal wastewater treatment. EPA CERI; EPA 625 88/022, Cincinnati, OH, USA.

Vymazal, J. (2005). Horizontal sub-surface flow and hybrid constructed wetlands systems for wastewater treatment. Ecol. Eng., 25(5), 478-490. https://doi.org/10.1016/j.ecoleng.2005.07.010

Vymazal, J. (2009). The use constructed wetlands with horizontal sub-surface flow for various types of wastewater. Ecol. Eng., 35(1), 1-17. https://doi.org/10.1016/j.ecoleng.2008.08.016

Wallace, S., Parkin, G., \& Cross, C. (2000). Cold climate wetlands design \& performance. Water Sci. Techno., 44(11-12), 259-265. https://doi.org/10.2166/wst.2001.0838

Winter, K. J., \& Goetz, D. (2003). The impact of sewage composition on the soil clogging phenomena of vertical flow constructed wetlands. Water Sci. Techno., 48(5), 9-14. https://doi.org/10.2166/wst.2003.0268

Zedler, J. B. (2003). Wetlands at your service: Reducing impacts of agriculture at the watershed scale. Front Ecol. Environ, 1(2), 65-72. https://doi.org/10.1890/1540-9295(2003)001[0065:WAYSRI]2.0.CO;2

Zedler, J. B., \& Callaway, J. C. (1999). Tracking wetland restoration: Do mitigation sites follow desired trajectories? Restor. Ecol., 7, 69-73. https://doi.org/10.1046/j.1526-100X.1999.07108.x

Zhang, C. B., Liu, W. L., Wang, J., Ge, Y., Ge, Y., Chang, S. X., \& Chang, J. (2011). Effects of monocot and dicot types and species richness in mesocosm constructed wetlands on removal of pollutants from wastewater. Bioresour. Technol., 102, 10260-10265. https://doi.org/10.1016/j.biortech.2011.08.081

Zhang, J., Meng, F., Lu, Y., Jing, Y., Zhang, H., Zhang, B., \& Zhang, C. (2008). Ecological assessment of lakeshore wetland rehabilitation on eastern route of South-to-North Water Transfer Project Front. Environ. Sci. Eng. China, 2(3), 306-310. https://doi.org/10.1007/s11783-008-0057-1

\section{Copyrights}

Copyright for this article is retained by the author(s), with first publication rights granted to the journal.

This is an open-access article distributed under the terms and conditions of the Creative Commons Attribution license (http://creativecommons.org/licenses/by/4.0/). 